\title{
TRADUÇÃO
}

\section{COMO É SER UM MORCEGO? (1974)}

\author{
Thomas Nagel ${ }^{1}$
}

A consciência é o que torna o problema mente-corpo realmente intratável. Talvez seja por isso que as discussões atuais dão tão pouca atenção ou tratam o problema de forma enviesada. A recente onda de euforia reducionista produziu diversas análises do fenômeno mental, assim como conceitos mentais que ensaiavam explicar a possibilidade de algumas variações de materialismo, identificação psicofísica ou reducionismo². Mas os problemas em causa são os mesmos deste ou de outros tipos de reducionismo, e o que torna o problema mente-corpo realmente único - diversamente do problema da relação entre a água e a fórmula H2O; da máquina de Turing/ máquina da IBM; do problema do relâmpago/da descarga elétrica, o problema do gene/do DNA ou o problema da árvore de carvalho/hidrocarbono - continua sem resposta.

Cada reducionista tem sua analogia favorita na ciência moderna. E é improvável que qualquer um dos exemplos não relacionados de redução bem sucedida ilumine

\footnotetext{
Thomas Nagel (nascido em 1937) é filósofo norte-americano que leciona atualmente na Universidade de Filosofia e Direito na New York University. É especialista em Filosofia Política, Ética, Epistemologia e Filosofia da Mente. Tornou-se particularmente conhecido por sua crítica ao reducionismo relativo à concepção de "mente", a partir da publicação de seu ensaio "What Is It Like to Be a Bat?", publicado em 1974, além de suas contribuições sobre altruísmo. Publicou: The Possibility of Altruism (Oxford, 1970), Mortal Questions (Cambridge, 1979), The View From Nowhere (Oxford, 1986), What Does It All Mean? (Oxford, 1987), Equality and Partiality (Oxford, 1991), Other Minds (Oxford, 1995), The Last Word (Oxford, 1997), The Myth of Ownership: Taxes and Justice (with Liam Murphy) (Oxford, 2002), Concealment and Exposure (Oxford, 2002), e Secular Philosophy and the Religious Temperament (Oxford 2010). (N.do Ed.)

2 Por exemplo J. J. C. Smart, Philosophy and Scientifc Realism (Londres, 1963); David K. Lewis "An Argument for the Identity Theory", Journal of Philosophy, LXIII (1966), reimpresso com adenda em David M. Rosenthal, Materialism \& the Mind-Body Problem (Engelwood Cliffs, NJ.: Prentice-Hall, 1971); Hilary Putnam, "Psychological Predicates", em Art, Mind, \& Religion, ed. W. H. Capitan e D. D. Merrill (Pittsburgh: University of Pittsburgh Press, 1967), reimpresso em Materialism, ed. Rosenthal, como "The Nature of Mental States"; D. M. Armstrong, A Materialist Theory of the Mind (London: Routledge \& Kegan Paul, 1968); D. C. Dennett, Content and Consciousness (London: Routledge \& Kegan Paul, 1969). Eu expressei dúvidas anteriormente em "Armstrong on the Mind", Philosophical Review, LXXIX (1970), 394-403; uma revisão de Dennett, Journal of Philosophy, LXIX (1972); e capítulo 11 acima. Veja também Saul Kripke, "Naming and Necessity". em Semantics of Natural Language, ed. D. Davidson e G. Harman (Dordrecht: Reidel, 1972), esp. pp. 334-42; e M. T. Thornton, "Ostensive Terms and Materialism", The Monist, LVI (1972), 193-214.
}

um pouco melhor a relação da mente com o cérebro. Mas os filósofos compartilham da fraqueza de toda a espécie humana por explicações do que é incompreensível em termos próximos ao que é familiar e bem compreendido, mesmo que completamente diferentes. Isso conduziu à aceitação de resultados implausíveis da realidade mental, porque permitiam tipos familiares de redução. Eu tentarei explicar porque os exemplos usuais não nos auxiliam a compreender a relação entre a mente e o corpo - por que, na verdade, nós ainda não concebemos como poderia ser uma explicação de natureza física de um fenômeno mental. Sem a consciência, o problema mente-corpo seria muito menos interessante. Com a consciência ele parece impraticável. O traço mais importante e característico dos fenômenos mentais conscientes fica compreendido de forma muito pobre. Muitas teorias reducionistas nem mesmo tentam explicá-lo. E um exame cuidadoso mostrará que não existe uma concepção de redução aplicável ao caso. Talvez fosse viável imaginar um novo modelo teórico com este propósito, mas esta solução, se existir, jaz num distante futuro intelectual.

A experiência consciente é um fenômeno difundido. Ela acontece em muitos níveis da vida animal, apesar de não estarmos certos de sua presença em organismos simples, da mesma forma que é difícil dizer, em geral, o que promove evidências dele (alguns extremistas andaram preparados para negá-lo mesmo em outros mamíferos além do ser humano). Sem dúvida, aparece em incontáveis formas totalmente inimagináveis para nós, em outros planetas e outros sistemas solares no universo inteiro. Mas como seja que a forma varie, o fato é que se um organismo tem alguma forma de experiência consciente, então há algo que é sentir-se como esse organismo. Pode haver implicações ulteriores da forma da experiência; pode até mesmo haver (o que eu duvido) implicações sobre o comportamento do organismo. Mas fundamentalmente um organismo tem estados mentais conscientes se e somente se há algo que é sentir-se ser este organismo alguma coisa que é sentir ser para o organismo.

A isso podemos denominar como o caráter subjetivo da experiência. Este não pode ser capturado por uma das análises mentais redutivas familiares e recentemente imaginadas, todas logicamente compatíveis com sua ausência. Nem é analisável em termos de qualquer sistema 
explicativo de estados funcionais, ou estados intencionais, uma vez que estes podem ser atribuídos a robôs ou autômatos, cujo comportamento assemelha-se ao humano, mas eles não experienciam nada ${ }^{3}$. Não é analisável em termos do papel causal das experiências em relação ao comportamento humano típico, por razões similares ${ }^{4}$. Não nego que estados mentais conscientes e eventos causem o comportamento, nem que eles possam receber caracterizações funcionais. Nego apenas que isso esgote as análises. Qualquer programa reducionista tem que estar embasado em uma análise do que está sendo reduzido. Se a análise deixar algo de fora, o problema terá sido enunciado de modo falso. É inútil embasar a defesa do materialismo em qualquer análise do fenômeno mental que falhe em lidar explicitamente com seu caráter subjetivo. Pois não há razão para se supor que uma redução que parece plausível quando não é feita tentativa de considerar a consciência, possa ser estendida para incluir a consciência. Portanto, sem alguma ideia do que seja o caráter subjetivo da experiência, nós não podemos saber o que é requerido por uma teoria fisicalista.

Enquanto parece que uma consideração das bases físicas da mente deva explicar muitas coisas, isso parece ser o mais difícil. É impossível excluir o aspecto fenomenológico de uma experiência de redução da mesma maneira que alguém exclui o aspecto fenomênico de uma substância comum de sua redução física ou química isto é, explicando-as como resultado da mente humana do observador ${ }^{5}$. Se se trata de defender o fisicalismo, os próprios aspectos fenomenológicos devem receber uma abordagem física. Mas quando examinamos seu caráter subjetivo, parece impossível este tipo de resultado. A razão é que cada fenômeno subjetivo está essencialmente conectado a um ponto de vista singular, e parece inevitável que uma teoria física objetiva o abandonará.

Deixe-me primeiro tentar explicar o problema de modo mais completo do que referindo-me à relação entre o subjetivo e o objetivo, ou entre o pour-soi e o en-soi. Isso não é nada fácil. Fatos relacionados como é ser um X são muito peculiares, tão peculiares que alguns podem inclinar-se a pôr sua realidade, ou o significado dela, em dúvida. Para ilustrar a conexão entre a subjetividade e um ponto de vista, e para evidenciar a importância dos aspectos subjetivos, será útil explorar a matéria em relação a um exemplo que revelará claramente a divergência entre os dois tipos de concepção, o subjetivo e o objetivo.

\footnotetext{
3 Talvez não fosse possível existir esse tipo de robô atualmente. Talvez algo suficientemente complexo para comportar-se como uma pessoa poderia vir a ter experiências. Mas isso, se for verdadeiro, é um fato que não pode ser descoberto mediante a pura análise do conceito de experiência.

4 Isso não é equivalente àquilo sobre o que somos incorrigíveis, por que nós não somos incorrigíveis sobre a experiência e porque a experiência está presente em animais que carecem de linguagem e pensamentos, e que não possuem crenças associadas às suas experiências.

5 Cf. Richard Rorty, "Mind-Body Identity, Privacy, and Categories", The Review of Metaphysics, XIX (1965), esp. 37-38.
}

Presumo que todos nós acreditamos que os morcegos possuem experiência. Afinal, eles são mamíferos e não se duvida da experiência deles, tanto quanto que um rato, pombos ou as baleias têm experiência. Eu escolhi os morcegos ao invés de vespas ou do linguado porque, na medida em que vamos descendo na árvore filogenética, as pessoas vão diluindo a própria fé de que seja possível encontrar experiência. Os morcegos, apesar de mais próximos em relação a nós do que as outras espécies, apresentam um espectro de atividade tão diverso e um dispositivo sensorial tão estranho ao nosso que o problema que eu desejo apresentar é extraordinariamente vívido (apesar de ser possível encontrar algo similar em outras espécies). Qualquer pessoa que, mesmo sem os benefícios da reflexão filosófica, já tenha passado algum tempo num espaço fechado com um morcego agitado sabe muito bem o que significa encontrar uma forma de vida fundamentalmente alienígena.

Eu disse que a essência da crença de que os morcegos têm experiência é que existe algo como ser ser um morcego. Agora nós sabemos que a maioria dos morcegos (para ser preciso, os microquirópteros) percebem o mundo exterior principalmente por meio do sonar ou ecolocalização, detectando a reflexão dos seus próprios guinchos rápidos e de alta frequência em objetos circunstantes. Seus cérebros são projetados para correlacionar os impulsos emitidos com os ecos subsequentes e a informação assim obtida habilita-os a fazer discriminações precisas de distância, tamanho, forma, movimento e textura, comparáveis às que fazemos através da visão. Mas o sonar do morcego, claramente uma forma de percepção, não é similar em sua operação a nenhum dos nossos sentidos, e não há razão para que suponhamos que seja subjetivamente parecido a qualquer coisa que nós podemos experienciar ou imaginar. Isto parece criar dificuldades para a noção do que é ser um morcego. Devemos refletir se existe algum método capaz de nos permitir extrapolar do nosso próprio exemplo ${ }^{6}$ para a vida interna de um morcego; em caso contrário, que outro método pode haver para a compreensão da noção?

Nossas próprias experiências fornecem material básico para nossa imaginação, cujo alcance fica limitado por essa mesma razão. Não vai ajudar muito tentar imaginar que alguém teceu seus braços, os quais o habilitam a voar do anoitecer até à alvorada capturando insetos com a boca; que alguém tem uma visão pobre e percebe o mundo que o cerca através de um sistema de reflexos de sinais sonoros de alta frequência; que alguém passa o dia dependurado de cabeça para baixo com os pés fixos no teto. Até onde posso imaginar (e não consigo ir muito longe) isso me fornece dados apenas sobre o que poderia ser para mim comportar-me como um morcego se comporta. Mas esta não é a questão. Eu queria mesmo saber

\footnotetext{
6 “nosso próprio exemplo" não significa "meu próprio exemplo", mas ideias mentalistas que aplicamos acriticamente a nós mesmos e a outros seres humanos.
} 
como é, para um morcego, ser um morcego. Mesmo se eu tentasse imaginar isso, estaria restrito às faculdades de minha própria mente, e estas são inadequadas para a tarefa. Eu não posso realizar a tarefa nem imaginando adições às minhas experiências atuais, nem graduais subtrações, nem imaginar eventuais combinações de adições, subtrações e modificações.

Se eu pudesse olhar e portar-me como uma vespa ou um morcego, sem alterar minha estrutura fundamental, minhas experiências não seriam nada parecidas com as desses outros animais. Por outro lado, é suspeito que qualquer significado possa estar vinculado à suposição de que eu poderia possuir a constituição neurofisiológica interna de um morcego. Mesmo se eu pudesse gradualmente ser transformado em um morcego, nada em minha constituição atual me habilita a imaginar com o que as experiências desse tipo, numa etapa futura e de acordo com essa metamorfose, poderiam ser parecidas. A melhor evidência poderia vir das experiências dos próprios morcegos, se nós soubéssemos como elas são para eles.

Assim, se a ideia de como é ser um morcego depende de uma extrapolação do nosso próprio exemplo, a extrapolação deve ser incompletável. Nós não podemos ir além de uma concepção esquemática de como é ser. Por exemplo, podemos nos referir a tipos gerais de experiência à base da estrutura e comportamento animal. Dessa maneira, descrevemos o sonar do morcego como uma forma tridimensional de enviar percepções; acreditamos que os morcegos sentem alguma forma de dor, medo, fome e luxúria, e que eles têm outros tipos mais familiares de percepções, além do sonar. Mas nós acreditamos que essas experiências também têm, em cada caso, um caráter subjetivo específico, os quais extrapolam a nossa habilidade para concebê-los. Se é concebível vida consciente em outro lugar no universo, é provável que algumas de suas formas não serão descritíveis, nem mesmo nos termos experienciais mais gerais que estão disponíveis para nós ${ }^{7}$ (o problema não está confinado aos casos mais exóticos, pois ele existe entre uma pessoa e outra. O caráter subjetivo da experiência de uma pessoa surda e cega de nascimento não está acessível a mim, por exemplo, do mesmo modo que nem a minha para ele. Isso não nos dispensa de acreditar que as experiências dos outros têm um caráter subjetivo).

Se alguém se inclina a negar que podemos acreditar na existência de fatos como estes, cuja natureza exata nós não podemos conceber, deveria refletir que ao contemplar os morcegos nós ficamos na exata posição em que mor-

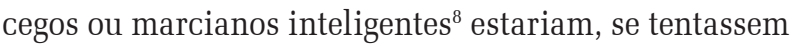
formar uma concepção do que é ser ser um de nós. A própria estrutura de suas mentes pode tornar isso impossível para eles, mas nós sabemos que eles estariam errados em

\footnotetext{
7 Por essa razão a forma analógica da expressão em inglês "o que isto parece" [what it is like] é enganosa. Ela não significa "o que (em nossas experiências) isto parece", mas antes "como isto é / aparece para o sujeito mesmo".

8 Qualquer extraterrestre inteligente é totalmente diferente de nós.
}

concluir que não precisam de nada para sentir-se ser um de nós: que somente certos tipos gerais de estados mentais poderiam referir-se a nós (talvez percepção e apetite pudessem vir a ser concebidos em comum; talvez nem isso). Nós sabemos que eles estariam errados em extrair uma conclusão cética porque sabemos o que é ser como nós mesmos. E nós sabemos que ao mesmo tempo isto inclui uma soma enorme de variantes e complexidades, que não possuímos um vocabulário para descrever adequadamente; seu caráter subjetivo é altamente específico e, em alguns aspectos, descrito em termos que podem ser compreendidos somente por criaturas como nós. O fato de que nós não podemos esperar eternamente para acomodar em nossa linguagem uma descrição fenomenológica detalhada de um marciano, ou de um morcego, não deveria nos levar a descartar como insignificante a pretensão de que os morcegos e os marcianos tenham experiências perfeitamente comparáveis, em riqueza de detalhes, às nossas próprias. Seria lindo se alguém desenvolvesse os conceitos e uma teoria que nos habilitasse a pensar sobre estas coisas; mas esse tipo de compreensão pode estar permanentemente negado a nós, pelos limites da nossa natureza. Negar a realidade, ou o significado lógico do que nós jamais poderemos descrever ou compreender, é a forma mais primitiva da dissonância cognitiva.

Isto nos traz à fronteira de um tópico que requer muito mais discussão do que eu posso fornecer por enquanto: a relação entre os fatos, de um lado, e esquemas conceituais ou sistemas de representação, do outro. Meu realismo sobre o domínio subjetivo em todas as suas formas implica numa crença na existência de fatos além dos que os conceitos humanos podem alcançar. Certamente é possível para um ser humano acreditar que há fatos que os humanos jamais irão possuir os conceitos requeridos para representar ou compreender. Poderia ser tolo duvidar disso, dada a limitação das expectativas humanas. Afinal, alguém teria descoberto os números transfinitos, mesmo se todos os seres humanos tivessem sido eliminados pela peste negra antes que Cantor os descobrisse. Mas alguém pode também acreditar que há fatos que não poderiam ser representados ou compreendidos pelos seres humanos, mesmo se a espécie conservar-se eternamente - simplesmente porque nossa estrutura não nos permite operar com conceitos do tipo requerido. Esta impossibilidade pode ser observada mesmo por outros seres, mas daí não segue que é necessária a existência desse tipo de seres para a significação da hipótese de que há fatos inacessíveis à humanidade (afinal a natureza dos seres com acesso a fatos inacessíveis à humanidade é presumivelmente um fato inacessível à humanidade). Refletir sobre como é ser um morcego parece conduzir-nos, então, até à conclusão de que há fatos que não consistem, na verdade, de proposições exprimíveis em linguagem humana. Nós podemos ser compelidos a reconhecer a existência deste tipo de fatos sem estarmos aptos a representá-los ou compreendê-los. 
Entretanto, não vou seguir com o assunto. Ele é importante para o nosso tópico (isto é, o problema mente-corpo) porque nos habilita a tecer uma observação geral sobre o caráter subjetivo da experiência. Qualquer que seja o status dos fatos sobre o que é sentir-se um ser humano, um morcego ou um marciano, estes parecem serem fatos que incorporam um ponto de vista particular.

Eu não estou levantando aqui a tese da privatização da experiência ao seu possuidor. O ponto de vista em questão não está acessível apenas a um indivíduo singular. Mais que isso, trata-se de um tipo. Com frequência é possível adotar um outro ponto de vista diferente do próprio, de forma a que a compreensão dos fatos não se restrinja a um caso particular. Há um sentido no qual os fatos fenomenológicos são perfeitamente objetivos: uma pessoa pode saber ou dizer, de outra pessoa, qual é a qualidade da experiência dessa outra. Os fatos são subjetivos, no sentido em que mesmo esta adscrição objetiva da experiência pode ser acessado por alguém suficientemente familiarizado com o objeto do relato e estará apto a adotar aquele ponto de vista - isto é, para compreender o relato na primeira, bem como na terceira pessoa, por assim dizer. Quanto mais um experienciador é estranho a outro, tanto menor virá a ser o sucesso que um ou outro pode esperar da iniciativa. Em nosso caso, nós ocupamos o ponto de vista relevante, mas nós teremos tanta dificuldade em compreender as nossas próprias experiências adequadamente, se nós a abordarmos do ponto de vista de outro, tanto quanto teríamos se tentássemos compreender a experiência de outra espécie sem adotarmos seu ponto de vista ${ }^{9}$.

Isso conduz diretamente ao problema mente-corpo. Se os fatos da experiência - fatos sobre como é sentir-se para o organismo experienciando - são acessíveis somente de um único ponto de vista, então é um mistério como o verdadeiro caráter da experiência poderia ser revelado na operação física deste organismo. Trata-se do domínio dos fatos objetivos por excelência - do tipo que pode ser observado e compreendido por meio de muitos pontos de vista, e através de pessoas com diferentes sistemas per-

\footnotetext{
Pode ser mais fácil do que suponho transcender barreiras entre espécies com a ajuda da imaginação. Por exemplo, as pessoas cegas têm habilidade para detectar objetos próximos a elas através de uma forma de sonar, usando cliques vocais ou dando pancadinhas com uma bengala. Talvez se uma pessoa soubesse ao que isso se assemelha ela poderia, por extensão, imaginar primariamente o que era possuir um sonar muito mais refinado, como o dos morcegos. A distância entre uma pessoa e as outras, assim como com outras espécies, poderia consequentemente diminuir. Mesmo para outras pessoas a compreensão do que é sentir-se como eles é somente parcial, e quando alguém desloca-se para uma espécie completamente diferente da sua, um grau ainda menor de compreensão pode estar disponível. A imaginação é extraordinariamente flexível. Minha questão, entretanto, não é que nós não podemos saber como é ser um morcego. Não estou tentando formular o problema epistemológico. Meu ponto é que antes mesmo de formar uma concepção do que é sentir-se um morcego (e ainda mais conclusivo, saber como é ser um morcego) uma pessoa deve adotar o ponto de vista dos morcegos. Se a pessoa pode adotá-lo, mesmo que de maneira primária ou parcial, então sua concepção também será primária ou parcial. O nosso estado atual de compreensão encontra-se nesse ponto.
}

ceptivos. Há obstáculos incomparáveis e inimagináveis para os cientistas humanos na obtenção de conhecimento sobre a neurofisiologia dos morcegos, e morcegos ou marcianos inteligentes podem aprender mais sobre o cérebro humano do que nós jamais conseguiremos.

Este não é por si só um argumento contra a redução. Um cientista marciano, sem compreensão da percepção visual, poderia ser capaz de compreender o arco-íris, o relâmpago ou as nuvens como fenômenos físicos, considerando que jamais estará apto a compreender o conceito humano do arco-íris, do relâmpago, das nuvens ou o lugar que estas coisas ocupam em nosso mundo fenomênico. A natureza objetiva das coisas percebidas por esses conceitos poderia ser apreendida por ele porque, apesar dos próprios conceitos serem conectados com um ponto de vista particular e uma visão fenomenológica particular, as coisas apreendidas desse ponto de vista não são: elas são observáveis através de um ponto de vista, mas ele é externo a elas; por essa razão elas podem ser compreendidas de outros pontos de vista, pelo mesmo organismo ou através de outro. $\mathrm{O}$ relâmpago possui um caráter objetivo que não é exaurido por sua aparência visual, e pode ser investigado por um marciano cego. Mais precisamente, ele possui um caráter objetivo maior do que o revelado por sua aparência visual. Falando do deslocamento da caracterização subjetiva para a objetiva, eu prefiro permanecer sem expressar minha opinião sobre a existência de um ponto final, a natureza objetiva completamente intrínseca de uma coisa, que alguém pode ou não estar apto a alcançar. Pode ser mais preciso pensar na objetividade como uma direção na qual a compreensão pode progredir. E ao compreender um fenômeno como o relâmpago, é legítimo ir tão longe quanto uma pessoa pode ir, dum ponto de vista estritamente humano ${ }^{10}$.

No caso da experiência, por outro lado, a proximidade com um ponto de vista particular parece maior. É difícil compreender, pelo caráter objetivo de uma experiência, o que poderia estar significando, separado de um ponto de vista particular, através do qual este sujeito a apreende. Afinal, o que poderia estar omitido em como é ser um morcego, se o ponto de vista do morcego for removido? Mas se a experiência não tem, somado ao seu caráter subjetivo, uma natureza objetiva que pode ser apreendida através de muitos pontos de vista diferentes, então como se pode supor que um marciano, investigando meu cérebro, pode estar observando processos físicos, os quais são meus processos mentais (como ele poderia observar os processos físicos tais como estar assustado com o relâmpago), somente através de um ponto de vista diferen-

\footnotetext{
${ }^{10}$ O problema que eu estou levantando pode então ser apresentado, mesmo se a distinção entre as descrições ou pontos de vista mais subjetivos ou mais objetivos puderem ser efetivadas somente no interior de um ponto de vista humano mais amplo. Eu não aceito esta forma de relativismo conceitual, mas ela não precisa ser refutada para que formulemos a questão que a redução psicofísica não pode ser acomodada pelo modelo da subjetividade para a objetividade, tão familiar em outros casos.
} 
te? Como poderia um pesquisador humano observar esta questão de um outro ponto de vista? ${ }^{11}$

Parece que estamos encontrando uma dificuldade geral com a redução psicofísica. Em outras áreas o processo de redução é um movimento em direção a uma maior objetividade, por uma visão mais acurada da natureza real das coisas. Isso se atinge pela redução de nossa dependência a um ponto de vista individual ou específico da espécie, através do objeto de investigação. Nós não o descrevemos em termos da impressão que ele causa em nossos sentidos, mas em termos dos seus efeitos mais gerais e das propriedades detectáveis através de outros meios que não os sentido humanos. Quanto menos isso depender do ponto de vista humano específico, maior é a objetividade da nossa descrição. É possível seguir este caminho porque, apesar dos conceitos e das ideias que nós empregamos para pensar o mundo exterior serem inicialmente aplicados de um ponto de vista que envolve nosso sistema perceptivo, nós os usamos para reportar coisas além deles mesmos - através dos quais nós temos o ponto de vista fenomênico. Por esta razão, nós podemos abandoná-los em favor de outro, e ainda assim estar pensando sobre as mesmas coisas.

A própria experiência, entretanto, não parece se adaptar ao modelo. A ideia de mudança da aparência para a realidade não faz sentido aqui. Qual é a analogia, neste caso, em procurar uma compreensão mais objetiva do mesmo fenômeno através do abandono do ponto de vista subjetivo inicial, em favor de outro que é mais objetivo mas relativo à mesma coisa? Certamente parece inverossímil que nós chegaremos mais perto da natureza real da experiência humana deixando para trás a particularidade do nosso ponto de vista, e empenhando-nos numa descrição em termos acessíveis a seres que não poderiam imaginar o que é sentir-se um de nós. Se o caráter subjetivo da experiência é completamente compreensível somente através de um ponto de vista, então qualquer substituição, visando a uma maior objetividade - isto é, menor conexão com um ponto de vista específico - não nos leva a uma maior aproximação com a natureza real do fenômeno: leva para longe.

Num certo sentido, as origens dessa objeção à redução da experiência já foi detectada nos casos de redução bem sucedidos; para descobrir que, na realidade, as vibrações sonoras são fenômenos ondulatórios no ar ou outros meios, nós esquecemos um ponto de vista para adotar outro, e o ponto de vista auditivo, humano ou animal que nós deixamos para trás, permanece sem redução. Membros de espécies radicalmente diferentes podem compreender os mesmos eventos físicos em termos objetivos, e isso não requer que eles compreendam as formas fenomenais com que estes eventos ocorrem nos

\footnotetext{
11 O problema não é exatamente que, quando eu olho a "Mona Lisa", minha experiência visual apresente certas qualidades que não se deixarão captar por alguém que eventualmente observe meu cérebro do exterior. Mesmo se ele observasse ali uma minúscula imagem da "Mona Lisa”, ele não teria razões para identificá-la com a experiência.
}

sentidos dos membros das outras espécies. Assim, para eles se referirem a uma realidade comum, uma condição é que seus pontos de vista mais particulares não são parte da realidade comum que eles apreendem. A redução pode ocorrer somente se o ponto de vista específico da espécie for omitido daquilo que está sendo submetido à operação de redução.

Mas ao mesmo tempo que nós estamos certos ao deixar de lado este ponto de vista na busca de uma completa compreensão do mundo exterior, não podemos ignorá-lo indefinidamente, já que ele é a essência do mundo interior, e não meramente um ponto de vista dele. Muito do novo behaviorismo na recente psicologia filosófica resulta do esforço em substituir uma concepção objetiva da mente por uma coisa real, com o objetivo de não omitir nada que não possa ser reduzido. Se nosso conhecimento de uma teoria física da mente deve considerar o caráter subjetivo da experiência, nós devemos admitir que atualmente não está disponível uma concepção que nos dê indícios de como isso poderia ser feito. O problema é único. Se os processos mentais são realmente processos físicos, então deve haver alguma coisa que é, intrinsecamente, ${ }^{12}$

\footnotetext{
${ }^{12}$ A relação então não seria contingente, como que entre uma causa e seus diferentes efeitos. Seria necessariamente verdadeiro se um certo estado físico sente de uma certa maneira. Saul Kripke (op. cit.) argumenta que o behaviorismo causal e análises relativas ao mental falham porque eles constroem, por exemplo, "dor" como meramente um nome contingente para dores. O caráter subjetivo de uma experiência ("e sua imediata qualidade fenomenológica", como Kripke denomina [p. 340]) é a propriedade essencial omitida por essas análises, e a propriedade em virtude da qual ela é, necessariamente, a experiência que ela é. Minha visão é próxima da dele. Como Kripke, eu descobri a hipótese de que um certo estado cerebral poderia ter necessariamente um certo caráter subjetivo incompreensível sem explicações adicionais. Estas explicações não emergem de teorias que veem a relação mente-cérebro como contingente, mas talvez haja outras alternativas ainda não descobertas. Uma teoria que explicasse como a relação mente-cérebro fosse necessária ainda nos deixaria com o problema de Kripke, de explicar por que motivo, apesar disso, apresenta-se contingente. Esta dificuldade parece para mim superável da seguinte maneira: nós podemos imaginar algo através de sua representação para nós mesmos tanto perceptiva, empática ou simbolicamente. Não tentarei dizer como trabalhar com a imaginação simbólica, mas pontuar parte do que ocorre nos outros dois casos. Para imaginar algo perceptivamente, nós nos colocamos num estado consciente semelhante ao estado em que estaríamos se nós percebêssemos isso. Para imaginar algo empaticamente, colocar-nos-íamos em um estado consciente parecido com este algo. (Este método pode ser usado somente para imaginar eventos e estados mentais - no nosso próprio caso, ou no de outros.) Quando nós tentamos imaginar um estado mental ocorrendo sem seu estado cerebral associado, primeiro empaticamente imaginamos a ocorrência do estado mental: isto é, nós nos colocamos dentro de um estado que se assemelha a ele mentalmente. Ao mesmo tempo, nós tentamos perceptivamente imaginar a não ocorrência do estado físico associado, colocando-nos dentro de outro estado não conectado com o primeiro: um semelhante ao qual nós estaríamos se nós não percebêssemos a ocorrência do estado físico. Onde a imaginação dos aspectos físicos é perceptual e a imaginação de aspectos mentais é empática, isso parecer-nos-ia que poderíamos imaginar qualquer experiência ocorrendo sem estados cerebrais associados, e vice-versa. A relação entre eles parecerá contingente mesmo se for necessária, por motivo da independência dos diversos tipos de imaginação. (O Solipsismo, incidentalmente, ocorrerá, se alguém interpretar erroneamente a imaginação empática como se ela trabalhasse como a imaginação perceptiva: parecerá, então, impossível imaginar qualquer experiência que não seja a da própria pessoa).
} 
atravessar certos processos físicos. Qual é essa coisa permanece um mistério.

Que moral seria retirada dessas reflexões e o que poderia ser feito em seguida? Seria um engano concluir que o fisicalismo deve ser falso. Nada está provado pela inadequação das hipóteses fisicalistas que utilizam uma análise objetiva, mas falha, da mente. Seria mais verdadeiro dizer que o fisicalismo é uma posição que nós não podemos compreender, porque nós não temos atualmente qualquer concepção de que modo ele poderia ser verdadeiro. Talvez ele seja um conceito que sem razão requer uma concepção como uma condição para a própria compreensão. Afinal, poder-se-ia dizer, o significado do fisicalismo é suficientemente claro: estados mentais são estados do corpo; eventos mentais são eventos físicos. Nós não sabemos quais estados físicos e eventos eles são, o que não nos impede de compreender as hipóteses. O que poderia ser mais claro do que as palavras "é" e "são"?

Mas eu acredito que é precisamente essa aparente clareza da palavra "é” que é decepcionante. Habitualmente quando nós estamos falando que X é Y, nós sabemos como é que isto se supõe ser verdadeiro, mas isso depende de uma base conceitual ou teórica, e não é comunicado pelo "é" sozinho. Nós sabemos como "x" e "y" referem-se e o tipo de coisas aos quais eles se referem, assim como nós temos uma ideia primária de como os dois caminhos referenciais podem convergir para uma única coisa, um objeto, uma pessoa, um processo, um evento ou qualquer coisa. Mas quando dois termos de identificação são muito discrepantes, pode não ser tão claro como isso poderia ser verdadeiro. Nós podemos não ter nem mesmo uma ideia tosca de como os dois caminhos referenciais poderiam convergir, ou para que tipo de coisas eles poderiam convergir, e uma estrutura teórica deve ser fornecida para habilitar-nos a compreender isso. Sem a estrutura, um ar de misticismo envolve a identificação.

Isso explica o sabor mágico das populares apresentações das descobertas científicas fundamentais, anunciadas como proposições que uma pessoa deve subscrever, sem na verdade compreendê-las. Por exemplo, as pessoas estão dizendo que no início da vida toda matéria é, na verdade, energia. Mas apesar do fato delas saberem o que "é" significa, a maioria delas jamais formou uma concepção do que torna esta afirmação verdadeira, porque elas carecem de uma base teórica.

Atualmente, o status do fisicalismo é similar ao que poderia ter sido a hipótese de que a matéria é energia se emitida por um filósofo Pré-Socrático. Nós não temos os princípios de uma concepção de como ele poderia ser verdadeiro. Com o objetivo de compreender a hipótese de que um evento mental é um evento físico, nós necessitamos mais do que uma compreensão da palavra "é". A ideia de como um termo pode referir-se, tanto mental como fisicamente à mesma coisa ainda está em falta, e as analogias habituais em outros campos da teoria da identificação falham em supri-la. Elas falham porque se nós construirmos, no modelo tradicional, termos referentes ao mental para os eventos físicos, tanto obtemos uma nova aparência dos eventos subjetivos separados, como dos efeitos através dos quais a referência mental para os eventos físicos ficam fechados, ou então obtemos uma ideia falsa de como os termos mentais se relacionam (por exemplo, o esquema causal behaviorista).

Estranhamente, nós podemos ter evidências para a verdade de algo que nós, na verdade, não podemos compreender. Suponha que um casulo foi trancado num cofre por alguém não familiarizado com a metamorfose dos insetos e, semanas mais tarde, o cofre é reaberto revelando uma borboleta. Se a pessoa sabe que o cofre ficou trancado todo este tempo, ele tem razão em acreditar que a borboleta é, ou era antes, o casulo, mesmo sem ter ideia de como isso pode ser assim (uma possibilidade é que 0 casulo continha um minúsculo parasita alado que o devorou e cresceu como uma borboleta).

É possível que nos encontremos na mesma posição em relação ao fisicalismo. Donald Davidson argumentou que se os eventos mentais têm causas e efeitos físicos, eles devem ter descrições físicas. Ele defende que nós temos razões para acreditar nisso, exatamente pensando que nós não devemos - e de fato não poderíamos - ter uma teoria geral psicofisiológica ${ }^{13}$. Seu argumento utiliza eventos mentais intencionais, mas eu penso que nós também temos alguma razão para acreditar que as sensações são processos físicos, sem estar na posição de compreender como. A posição de Davidson é que certos eventos físicos têm irredutíveis propriedades mentais, e talvez algum aspecto descritível nesse caminho esteja correto. Mas de nenhum deles nós podemos formar agora uma concepção correspondente; tampouco temos a ideia de como poderia ser uma teoria que nos habilitaria a conceber isso ${ }^{14}$.

Pouquíssimo se tem trabalhado sobre a questão básica (da qual a menção ao cérebro pode ser inteiramente omitida), se qualquer sentido pode ser extraído das experiências tendo um caráter objetivo sob qualquer condição. Fazer sentido, em outras palavras, perguntar com o que as minhas experiências são na verdade parecidas, caso contrário, como elas aparecem para mim? Nós não podemos genuinamente compreender a hipótese de que a natureza delas é capturada pela descrição física, a menos que nós compreendamos a ideia mais fundamental de que elas têm uma natureza objetiva (ou que os processos objetivos podem ter uma natureza subjetiva) ${ }^{15}$.

\footnotetext{
${ }^{13}$ Veja "Mental Events", em Foster \& Swanson, Experience and Theory (Amherst, 1970); apesar de eu não entender o argumento contra as leis psicofisiológicas.

14 Observação similar aplica-se ao meu artigo "Physicalism", Philosophical Review LXXIV (1965), 339-56, reimpresso com adições em John O’Connor, Modern Materialism (Nova York, 1969).

15 Esta questão também está no coração do problema das mentes alheias, cuja íntima ligação com o problema da relação mente-corpo é frequentemente omitido. Se compreendermos bem como é que a experiência subjetiva pode ter uma natureza objetiva, torna-se possível compreender a existência de outros sujeitos, além de nós mesmos.
} 
Eu gostaria de concluir com uma proposta especulativa. Pode ser possível abordar a divergência entre o subjetivo e o objetivo em outra direção. Pondo de lado temporariamente a relação entre a mente e o cérebro, nós podemos procurar uma compreensão mais objetiva do mental em sua própria defesa. Agora nós estamos completamente sem ferramentas para pensar sobre o caráter subjetivo da experiência, sem contar com a imaginação - sem adotar o ponto de vista do objeto experiencial. Isto pode ser considerado como uma provocação para formar novos conceitos, assim como inventar um novo método - uma fenomenologia objetiva não depende de empatia ou de imaginação. Pensando que presumivelmente ela poderia não capturar tudo, sua meta seria descrever, ao menos em parte, o caráter subjetivo das experiências de uma forma compreensível para seres incapazes de ter aquelas experiências.

Deveríamos desenvolver como que uma fenomenologia para descrever o sonar experienciado pelos morcegos; mas poderia também ser possível iniciar com humanos. Alguém poderia tentar, por exemplo, desenvolver conceitos que seriam usados para explicar para uma pessoa cega de nascimento como seria a experiência da visão. Poderíamos até trombar com um muro branco, mas poderia também vir a ser possível inventar um método para expressar em termos objetivos muito mais do que nós podemos atualmente, e com maior precisão. Libertar as analogias intermodais - por exemplo, "o vermelho é parecido com o som de uma trombeta" - as quais surgem em debates sobre esses temas e são pouco usadas. Isso ficaria claro para qualquer um que tenha ouvido uma trombeta e visto o vermelho. Mas aspectos estruturais da percepção seriam mais acessíveis para a descrição objetiva, mesmo pensando que alguma coisa pode estar omitida. E conceitos alternativos, que nós aprendemos em primeira pessoa, podem habilitar-nos a chegar a uma forma de compreensão mesmo da nossa própria experiência, a qual é negada, pela facilidade descritiva e falta de objetividade que os conceitos subjetivos necessitam.

Além do seu próprio interesse, uma fenomenologia que seja objetiva neste sentido, pode permitir que questões sobre as bases físicas ${ }^{16}$ das experiências assumam uma forma mais inteligível. Aspectos da experiência subjetiva que admitem este tipo de descrição objetiva poderiam ser melhores candidatos para um tipo mais familiar de explicação objetiva. Mas se esta suposição está correta ou não, parece improvável que qualquer teoria física da mente pode ser contemplada até que mais ideias sejam dadas sobre o problema geral da subjetividade e da objetividade. Caso contrário, não podemos nem mesmo apresentar o problema mente-corpo sem evitá-lo ${ }^{17}$.

Tradução: Josemar de Campos Maciel (Universidade Católica Dom Bosco/MS)

\footnotetext{
${ }^{16}$ Eu não dei uma definição de "físico". Obviamente ele não se aplica apenas ao que pode ser descrito pelos conceitos da física contemporânea, uma vez que nós esperamos maiores desenvolvimentos. Alguns podem pensar que não há como evitar que fenômenos mentais sejam eventualmente reconhecidos como físicos em sentido próprio. Mas não importa o que se diga do físico, ele deve ser objetivo. Assim, se a nossa ideia do físico se expande continuamente para incluir os fenômenos mentais, ela deverá então designar-lhes um caráter objetivo - seja isto feito, ou não, mediante a sua análise nos termos de outros fenômenos que já sejam vistos como físicos. Parece-me mais verossímil, entretanto, que a relação entre o mental e o físico será eventualmente melhor expressa por uma teoria cujos termos fundamentais não possam ser colocados claramente em nenhuma das duas categorias.

${ }^{17}$ Eu apresentei versões deste artigo a vários grupos de pessoas, e reconheço meu débito para com muitas pessoas, pelos seus comentários.
} 